\title{
The Importance of Learning Taxes Nowadays for Accounting Students
}

\author{
Meiliyah Ariani ${ }^{1}$, Zulhawati $^{2}$ \\ \{meiliyahariannie@yahoo.co.uk ${ }^{1}$, zulhawati@gmail.com² ${ }^{2}$,
}

\begin{abstract}
${ }^{1}$ Faculty of Economics and Business, Universitas Prof. Dr. Moestopo (Beragama) Jakarta, Indonesia ${ }^{2}$ Faculty of Business, Psychology and Communication, Universitas Teknologi Yogyakarta, Indonesia
\end{abstract}

\begin{abstract}
This study aims to examine the influence of career, economic, and quality motivations on students' interest in accounting for participating in tax audits. Career motivation variable is measured by promotion, good judgment, desire to get a degree, improve career, and professional development. Economic motivation variable are measured by salaries of remuneration, pension plans and benefits. Variable quality motivation is measured by ability, increasing expertise and professionalism. Accounting student's interest variable is measured by adding knowledge, salary, work suitability, and supporting the quality of students. The sample method is done by purposive sampling. The number of students sampled in this study was 82 accounting students at University of Professor DR. Moestopo (Religion) Faculty of Economics and Business, semester VI, VII, and VIII. The data used is primary data in the form of questionnaires distributed to respondents. Data analysis method used in this research is multiple regression analysis. The results of this study indicate that career, economic motivation and overall quality affect the interest of accounting students to participate in tax audits. Partially, this study shows that career motivation and quality have a positive effect on students' interest in accounting for participating in tax audits, while economic motivation has a negative effect on students' interest in accounting for participating in tax returns.
\end{abstract}

Keywords: Career Motivation, Economic Motivation, Quality Motivation, Interest Of Accounting Students.

\section{Introduction}

The role of tax consultants on the state is quite large, one of which is helping taxpayers in exercising their rights and fulfilling their tax obligations in accordance with tax laws, this is stated in the regulation of the Minister of Finance No. 111 / PMK.03 / 2014 concerning tax consultants. Tax consultants in Indonesia are currently lacking when compared to the number of taxpayers. Tax consultants in Indonesia currently number 4,500 people, this number is still very small to support the performance of the Directorate General of Taxes (DGT), while Indonesia has a number of taxpayers and a population of nearly 250 million. Details of the number of tax consultants from 2014-2018, can be seen in the table below: 
Table 1.1. Number of the Consultant

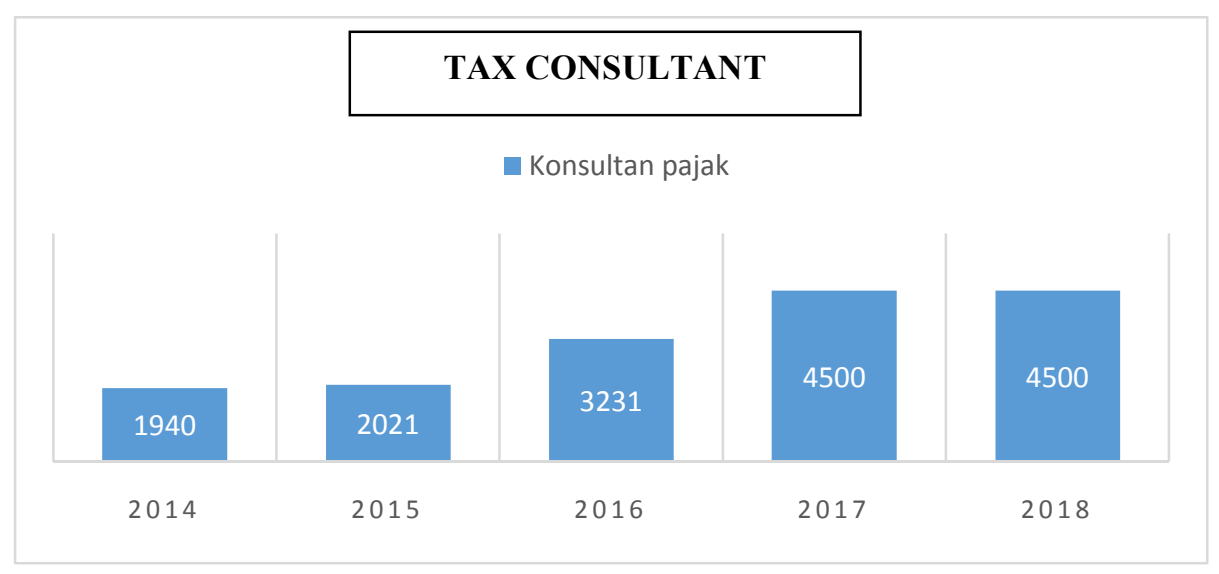

Based on the table above, it can be concluded that the Indonesian state currently lacks consultants to remember the number of Indonesian citizens who are more than 250 million people, so it is hoped that Indonesia can increase the number of consultants for each year.

The Brevet tax education is a professional education program for prospective tax consultants or practitioners who have an interest in working in the tax division of a business or non-business organization. Following training in tax breeding is the first step for taking part in the training, one will get a certificate of brevet tax training. This certification is a requirement for participants who want to take the Tax Consultant Certification Exam (USKP). Where the USKP is a requirement to work as a Tax Consultant (Sarjono, 2011) [1].

The interest of accounting students who follow tax breeding is generally motivated by the desire to work as accountants as well as to complete the profession and attract companies through certificates that have been obtained (Trisnawati, 2013) [2].

According to Sarjono (2011) [1], careers are perceptions that measure one's desires that arise from within themselves to improve their personal abilities in order to achieve positions, positions, and careers that are better than before. Career choice is an expression of one's self, because choice shows one's motivation, knowledge, personality and all abilities possessed. Career motivation will encourage students to improve their abilities by participating in training in tax brevet to achieve a better position or position in their work later.

Another factor is the existence of quality motivation, in moving the quality to develop themselves, there must be intention, strong ability and giving up time spent in achieving better quality for the future (Minan, 2011) [3]. Quality motivation will improve the quality of accounting graduates, especially graduates in the field of tax so that it can be a separate value in the eyes of the companies they enter. Understanding knowledge about taxes more deeply is needed, given the high demand of the state for those who control the taxation sector. At present there are many ways that can be taken to obtain information and knowledge about taxes, one of which is brevet tax.

The purpose of the research that will be carried out is to obtain empirical evidence regarding the influence of career, economic, and quality motivation on the interest of accounting students in training in tax brevet. 


\section{Literature Review}

\section{1. Theory of Planned Behavior}

Theory of planned behavior is an attitude model that is used to predict the intention or interest of someone to do a behavior. According to this theory decision making is driven by rational evaluation and consequences for behavior, positive and negative consequences can influence a person's behavior. Theory of Planned Behavior explains that the intention or interest of someone to do a behavior or action becomes the main factor that influences a person's behavior (Sumarwan, 2015) [4].

According to Tirada (2013) [5], the emergence of intention to behave is determined by three factors, namely:

1. Behavioral Beliefs

2. Normative Beliefs

3. Control Beliefs

\section{2. Motivation}

Widiastuti and Suryaningsum (2005) [6] state that motivation is often interpreted as encouragement. Encouragement or energy is the movement of the soul and body to do, so that motivation is a force that moves humans to behave in their actions that have a specific purpose.

From the understanding of motivation that has been explained above, it can be concluded that motivation is an impulse that arises from within a person so that someone is moved to do an action in accordance with the goals to be achieved.

\section{3. Tax Brevet}

According to Sutrawati (2017) [7] brevet tax is a tax training or course without or with application to tax software. Holding tax brevet is to equip participants and students who participate in tax brevet with knowledge and skills in the field of taxation. Brevet tax has levels according to the material taught.

According to Sarjono (2011) [1] the tax brevet education program is an out-of-school education program that intends to equip education participants with knowledge and skills in the field of taxation. This program is designed for a curriculum that is able to equip participants to carry out tax obligations and taxpayer rights professionally in practice both as corporate and individual taxpayers and can equip participants to take the Brevet Examination National Tax Consultants organized by the Ministry of Finance of the Republic of Indonesia and the Association Indonesian Tax Consultant (IKPI).

The objectives of Brevet Pajak According to Sarjono (2011) [1] are:

a. Provide an understanding of applicable tax obligations and how to fulfill these obligations.

b. Providing technical knowledge regarding taxation calculations and reporting.

c. Provide adequate knowledge that can help participants who wish to take the Tax Consultant Certification Exam (USKP).

d. Providing updates on the latest provisions in the world of taxation so that participants can keep up with the tax developments properly.

\section{4. Interest to Join Brevet Tax}

Interest is the tendency of a high heart towards something. Interest is interpreted as a feeling that prefers or attracts an activity that is indicated by desire, a tendency to pay attention 
to these activities without anyone telling, done with self-awareness and followed by happy feelings .

Another definition revealed by Hurlock (2007) [8] interest is a source of motivation that encourages someone to do what they want and freely choose. In addition, interest is also a constant tendency to pay attention and enjoy an activity accompanied by pleasure.

\section{5. Career Motivation}

According to Sarjono (2011) [1] careers are perceptions that measure someone's desires that arise from within themselves to improve their personal abilities in order to achieve positions, positions, and careers that are better than before.

According to Indrawati (2009), [9] a career is a person's expertise or professionalism in the field of knowledge which is assessed based on work experience that will contribute to organization. Career choice is an expression of one's self, because choice shows one's motivation, knowledge, personality and all abilities possessed.

From the definition above, it can be concluded that career motivation is an incentive that arises in a person to the opportunity to get equality in career development. Because of career motivation, it will encourage students to improve their abilities by participating in tax brevet training to achieve a better position or position in their work later.

\section{6. Economic Motivation}

Economic motivation is an impulse that arises in a person to improve his personal abilities in order to achieve the desired financial reward. In general, financial awards consist of direct awards and indirect awards (Benny and Yuskar, 2006) [10].

Economic motivation is judged by how much encouragement to increase economic rewards in the form of direct appreciation, such as payment of basic salary or basic wages, overtime / salary from overtime, payment for holidays, distribution of profits and various other forms of performance based bonuses. Whereas indirect awards include vacation payment insurance, sickness allowance, pension programs and various other benefits (Ayuningtyas and Prihatini, 2012) [11].

Based on the definition above, it can be concluded that economic motivation is an impulse that arises in a person for his personality in order to achieve the desired financial reward, namely to improve the welfare of his life.

\section{7. Quality Motivation}

According to Minan (2011) [3] quality motivation is in driving quality to develop oneself, there must be intention, strong ability and giving up time spent in achieving better quality for the future.

According to Ellya (2006) [10] to become a tax consultant students must always act as experts in the field of taxation, this can be started from formal education, namely when they are in college which can then be expanded through subsequent experiences in practice.

According to Ellya (2006) [10] to become a tax consultant students must always act as experts in the field of taxation, this can be started from formal education, namely when they are in college which can then be expanded through subsequent experiences in practice.

To become a tax consultant student must always act as experts in the field of taxation. Someone who has a brevet certificate will be seen more by a company or organization so that the opportunity to be recruited by the company is getting bigger.

From the definition above, it can be concluded that quality motivation can encourage one's desire to improve their quality to achieve a better life according to their wishes. 


\section{Hypothesis Development}

\section{1. The Influence of Career Motivation to the Interest in Joining Tax Brevet}

Career motivation is an impulse that arises from within a person to improve his ability to achieve a career that is better than before. According to Sarjono (2011) [1], careers are perceptions that measure one's desires that arise from within themselves to improve their personal abilities in order to achieve positions, positions, and careers that are better than before.

Career motivation will make students interested in participating in tax brevet because they want to pursue a higher career path. According to Indrawati (2009) [9], a career is a skill or professional someone in the field of knowledge that is assessed based on work experience that will contribute to the organization.

Based on this, the hypotheses that can be formulated are as follows:

H1 : Career motivation has a positive influence to the Interest of the accounting students to follow Tax Brevet

\section{2. The Influence of economy motivation to the interest in following Tax Brevet}

Economic motivation is a drive that arises in a person to make efforts to improve the welfare of his life. In general, financial awards consist of direct awards and indirect awards (Benny and Yuskar, 2006) [10].

Economic motivation is judged by how much encouragement to increase economic rewards in the form of direct appreciation, such as payment of basic salary or basic wages, overtime / salary from overtime, payment for holidays, distribution of profits and various other forms of performance based bonuses. Whereas indirect awards include vacation payment insurance, sickness allowance, pension programs and various other benefits (Ayuningtyas and Prihatini, 2012) [11].

Based on this, the hypotheses that can be formulated are as follows:

$\mathrm{H} 2$ : Economy motivation has a positive influence to the students of accounting in following Tax Brevet

\section{3. The Influence of quality motivation to the interest in joining tax brevet}

According to Widiastuti and Suyaningsum (2004) [6] motivation of quality as an impulse that arises in a person to have and improve the quality of themselves and their abilities in the field they are engaged in so that they can carry out their duties properly and correctly.

According to Ellya (2006) [10] to become a tax consultant students must always act as experts in the field of taxation, this can be started from formal education, namely when they are in college which can then be expanded through subsequent experiences in practice.

Based on this, the hypotheses that can be formulated are as follows:

H3 : Quality motivation has a positive influence to the interest of the accounting students in following tax brevet.

\section{4. The influence of career, economy and quality motivation to the interest of the accounting students in following tax brevet}

Career motivation is an impulse that arises in a person to the opportunity to get equality in career development, among others, through promotion. Because of career motivation, it will encourage students to improve their abilities by participating in tax brevet training to achieve a better position or position in their work later. 
Economic motivation is an impulse that arises in a person for his personality in order to achieve the desired financial award, namely to improve the welfare of his life. Quality motivation can encourage one's desire to improve their quality to achieve a better life according to their wishes.

Based on this, the hypotheses that can be formulated are as follows:

H4 : Career, economic, and quality motivation have a positive effect on students' interest in following tax brevet.

\section{Proposed Method}

This study uses a quantitative approach. The data source in this study is primary data. Primary data is a source of research data obtained directly from original sources (not through intermediaries) (Indriantoro, 2009) [12]. Primary data is specifically collected by researchers to answer research questions. The data collection technique in this study is through questionnaires, namely by conducting data collection presented in the form of statements to respondents, namely accounting students, Faculty of Economics and Business, University Prof. Dr. Moestopo (Beragama) semesters 6, 7 and 8.

The population in the study was University students Prof. DR. Moestopo (Beragama) Faculty of Economics and Business Accounting Study Program which is still active from 2014-2017, which is 156 students. The questionnaire will be distributed to accounting students in semesters 6,7 , and 8 , namely 82 questionnaires as a sample of respondents from the total number of accounting students in 2014-2017.

The sampling technique in this study used purposive sampling technique, consideration of the selection of accounting students in semesters 6,7 and 8 because the semester students had received taxation courses including introductory taxation I and introduction to taxation II, taxation II and lab, international taxation, tax management, audit tax and taxation seminars.

The scale used in the preparation of the questionnaire is scalable. In data analysis, researchers used SPSS software (Statistical Product and Service Solutions) for Windows version 23

\section{Result \& Discussion}

\subsection{The Description of The Respondents}

Respondents in this study amounted to 82 consisting of men as many as 44 respondents $(53.7 \%)$, while women as many as 38 respondents $(46.3 \%)$. Based on the year of college entrance (force), the respondents were VI semester students as many as 43 respondents $(52.4 \%)$, and VIII semester as many as 39 respondents $(47.6 \%)$.

\subsection{Data Quality Test}

Test data quality includes reliability testing and validity test using SPSS Ver.20. Reliability test was carried out by Cronbach Alpha test with Cronbach Alpha value $>0.60$ and validity test by looking at Correlated item-Total Correlation. $\mathrm{r}$ product moment table with a significance of $5 \%$. The reliability test results using Cronbach's Alpha, all measuring instruments of the dependent and independent variables are valid and reliable. The results obtained from the validity test show that all the calculated $r$ values are greater than the value of the $r$ table product moment at the 5\% significance level for $n 96$. It is 0.220 so it can be concluded that all statement items used as measuring instruments in this study are valid. 


\subsection{Classic Assumption Test}

The classic assumption test carried out in this study is the normality test using graph analysis (Normal Probability Plot), histogram, and the Kolmogorovsmirnov test on the dependent variable which is entirely normally distributed because the significance exceeds 0.05 .

The multicolonity test for the independent variable tolerance value indicates that there is no independent variable that has tolerance less than 0.10 (VIF below 10) so it can be concluded that all variable concepts do not contain multicollinearity.

The heterokedasitas test using Scatterplot graph analysis can be seen that there are no patterns that are random, and the points spread randomly and spread both above and below the number 0 on the $\mathrm{Y}$ axis, it can be concluded that there is no heterokedasticity in the regression model, so the regression model declared eligible for use.

\subsection{Determination Coefficient Test}

Based on table 15 in the attachment, it can be seen that the value of Adjusted R Square from the results of data processing of $62.3 \%$ or $(0.623)$. This shows that the independent variables in their influence on the dependent variable are $62.3 \%$ and the rest are influenced by other factors not examined, namely $37.7 \%$ or $(0.377)$.

\subsection{Discussion of the Hypothesis}

After testing the hypothesis, then the discussion of the hypothesis is explained, the explanation of which is based on the research variables. Discussion of hypotheses will be described systematically and sequentially in accordance with the explanation of the results of hypothesis testing.

\subsubsection{The influence of career motivation to the interest of the accounting students in joining tax brevet}

Based on the results of testing that has been done in this study, it proves that career motivation as measured by promotion, good judgment, desire to get a degree, improve career, and professional development have a positive and significant effect on the interest of University accounting students Prof. DR. Moestopo (Beragama) Faculty of Economics and Business to participate in tax brevet. This explains that career motivation is related to the interest of accounting students to participate in tax brevet, because students assume that participating in tax brevet can help improve their careers when entering the workforce later.

\subsubsection{The influence of economy motivation to the interest of the accounting students in following tax brevet}

Based on the results of testing that has been done in this study, proving that economic motivation as measured by salary or remuneration, pension plans and benefits has a negative and non-significant effect on the interest of University accounting students Prof. DR. Moestopo (Beragama) to participate in tax brevet. This is possible because of the factor of the students who think that working is not only to get a salary or reward, but to work according to what they like and in accordance with their comfort while working. 


\section{a. The influence of quality motivation to the interest of the accounting students in following tax brevet}

Based on the results of testing that has been done in this study, proving that quality motivation as measured by ability and increasing expertise and professionalism has a positive and significant effect on the interest of University accounting students Prof. DR. Moestopo (Beragama) to participate in tax brevet. This explains that accounting students think that tax brevets will help improve their ability and quality in the field of taxation, so students are motivated to take part in tax brevet which will help them to have better grades in the university environment or when entering the workforce because companies will look more at someone who have more ability and expertise.

b. The influence of career, economy, and quality simultaneously to the interest of the accounting students in following tax brevet

From the results of hypothesis analysis, it proves that career motivation, economy and quality have an overall influence (simultaneous) on the interest of University accounting students Prof. DR. Moestopo (Beragama) to participate in tax brevet

Career motivation has a positive and significant effect on the interest of accounting students to participate in tax brevet, because students assume that participating in tax brevet can help improve their careers when entering the workforce later.

Economic motivation has a positive effect on the interest of accounting students to participate in tax brevet because brevet tax can help students to achieve desired financial rewards and improve their welfare.

Quality motivation has a positive and significant effect on the interest of accounting students to participate in tax brevet. because accounting students assume that brevet tax will help improve the ability and quality of themselves in the field of taxation, so students are motivated to participate in tax brevet which will help them to have better grades in the university or when entering the workforce because the company will look more at someone who more ability and expertise.

\section{Conclusion}

Based on the results of the research and discussion of the hypotheses described in the previous section, the conclusions that can be taken are as follows:

Career motivation has a significant and positive effect on the interest of accounting students to participate in tax brevet, because students assume that participating in tax brevet can help improve their careers when entering the workforce later.

Economic motivation has a negative and insignificant effect on the interest of accounting students to take part in tax breeding. This is possible because of the factor of the students who think that working is not only to get a salary or reward, but works according to what they like and in accordance with their comfort when they work.

Quality motivation has a significant and positive effect on the interest of accounting students to participate in tax brevet, because accounting students assume that brevet taxation will help improve the ability and quality of themselves in the field of taxation, so students are motivated to follow brevet taxes that will help them to have better grades in the university environment or when entering the workforce because the company will look more at someone who has more ability and expertise. 
Effect of career motivation, economy, and overall quality on the interest of accounting students to participate in tax brevet. Career motivation variable states that students assume by participating in brevet tax can help improve their careers when entering the workforce later, economic motivation states that the interest of accounting students to participate in tax brevet because brevet tax can help students to achieve desired financial rewards and improve their welfare, quality motivation states that the interest of accounting students to participate in tax brevet, because accounting students assume that brevet tax will help improve the ability and quality of themselves in the field of taxation.

\section{References}

[1]. Sarjono, Bayu. (2011). Faktor-fakor yang mempengaruhi minat mengikuti program pendidikan brevet pajak di STIE Perbanas Surabaya. The Indonesian Accounting Review. Vol. 1, No. 1.

[2]. Trisnawati, Mei. (2013). Pengaruh persepsi dan motivasi terhadap minat mahasiswa jurusan akuntasi fakultas ekonomi dan bisnis Universitas Brawijaya berkarir di bidang perpajakan. Jurnal Ilmiah Mahasiswa FEB. Vol. 1, No.2.

[3]. Minan, Kresna. (2011). Pengaruh Motivasi Terhadap Minat Mahasiswa Akuntansi Untuk Mengikuti Pendidikan Profesi Akuntansi (PPAk). Skripsi. Fakultas Ekonomi dan Bisnis, STIE Harapan. Medan.

[4]. Sumarwan, U, dkk. (2015). Riset pemasaran dan konsumen. Cet pertama. Bogor : IPB Press.

[5]. Tryana, A. M. Tiraada. (2013). Kesadaran Perpajakan, Sanksi Pajak, Sikap Fiskus Terhadap Kepatuhan WPOP Dikabupaten Minahasa Selatan. Jurnal. Universitas Samratulangi Manado.

[6]. Widiastuti, Sri Wahyuni dan Suryaningsum, Sri. (2005). Pengaruh Motivasi Terhadap Minat Mahasiswa Akuntansi untuk Mengikuti Pendidikan Profesi Akuntansi (PPA). Jurnal Akuntansi dan Manajemen. Volume XVI Tahun 1 April 2005 Hal. 67-77.

[7]. Sutrawati, Yellysah, dkk. (2017). Pengaruh Pengetahuan Mahasiswa Akuntansi di Palembang Tentang Pajak dan Brevet Pajak Terhadap Minat Berprofesi di Bidang Perpajakan. Jurnal. STIE Multi Data Palembang.

[8]. Hurlock. B. E. (2007). Psikologi Perkembangan Suatu Pendekatan Sepanjang Rentang Kehidupan. Penerbit Erlangga. Jakarta.

[9]. Indrawati, Novita. 2009. Motivasi dan Minat Minat Mahasiswa Akuntansi untuk Mengikuti Pendidikan Profesi. Pekbis Jurnal, Volume 1, Nomor 2 (hlm. 124--130).

[10]. Benny, Ellya dan Yuskar. (2006). Pengaruh Motivasi Terhadap Minat Mahasiswa Akuntansi Untuk Mengikuti Pendidikan Profesi Akuntansi (PPAK). Simposium Nasional Akuntansi IX, Padang.

[11]. Ayuningtias dan Prihatini. (2012). Faktor-faktor yang mempengaruhi minat mahasiswa akuntansi untuk mengikuti pendidikan profesi akutansi. Juraksi, Vol. 1,No. 1, ISSN: 2301-9328

[12]. Indriantoro, N., dan Supomo, B. (2009). Metodologi Penelitian Bisnis Untuk Akuntansi dan Manajemen. Yogyakarta: BPFE.

[13]. Agustinus, Paseleng. (2013). Efektifitas Penagihan Pajak dengan Surat Teguran dan Surat Paksaterhadap Penerimaan Pajak Penghasilan. Jurnal EMBA. Vol 1, No 4. Hal 2371-2381. 
